\title{
Localization of the ultimobranchial gland, thyroid gland and parathyroid gland in long-legged buzzard (Buteo rufinus)"
}

\author{
Burcu ONUK, Murat KABAK \\ Ondokuz Mayıs University, Faculty of Veterinary Medicine, Department of Anatomy Kurupelit, SAMSUN
}

\begin{abstract}
Summary: The objective of this study to determine localization of ultimobranchial gland, specific for reptiles and bird, thyroid and parathyroid glands in long-legged buzzard. A total of eight adult long-legged buzzard, brought to clinics of faculty and could not be rescued with medical treatment, were used for the study. Thyroid gland was among the two branches of the furcula at the entrance of the thoracic inlet. The length, width and thickness of thyroid gland which was the largest of the inspected glands were $4.5 \pm 0.8 \mathrm{~mm}, 2.87 \pm 0.53 \mathrm{~mm}$ and $2.74 \pm 0.42 \mathrm{~mm}$, respectively. Parathyroid gland, the second largest gland, was seen as the a number on the right side, while it generally had two numbers (cranial and caudal) on the left side. While the length, width and thickness of the cranial parathyroid were $1.73 \pm 0.38 \mathrm{~mm}, 1.13 \pm 0.18 \mathrm{~mm}$ and $1.05 \pm 0.67 \mathrm{~mm}$, respectively, the same measurents for the caudal parathyroid were $1.13 \pm 0.23 \mathrm{~mm}, 0.94 \pm 0.21 \mathrm{~mm}$ and $0.59 \pm 0.16 \mathrm{~mm}$ respectively. Ultimobranchial gland was found to be asymmetric on both sides (right and left) and being very small. Ultimobranchial gland on the left side generally placed caudal of the caudal parathyroid gland and was determined at the level where begining of common carotid artery in inspected materials. Ultimobranchial gland on the right side was generally located at between oesophagotracheobronchial vein and oesophagotracheobronchial artery. The gland was oval shaped and its average length $1.7 \pm 0.47 \mathrm{~mm}$, width $0.94 \pm 0.35 \mathrm{~mm}$ and thickness $0.5 \pm 0.14 \mathrm{~mm}$ were determined. In conclusion, the localization of the inspected glands in long legged buzzard was similar to that of the other birds although differences observed in the numbers of parathyroid gland and sizes of the other all glands.
\end{abstract}

Key words: Anatomy, parathyroid gland, thyroid gland, ultimobranchial gland, long-legged buzzard.

\section{Kızıl şahinde (Buteo rufinus) glandula ultimobranchialis, glandula thyroidea ve glandula parathyroidea'nın lokalizasyonu}

Özet: $\mathrm{Bu}$ çalışma, sürüngen ve kanatlllara özgü olan glandula ultimobranchialis ile glandula thyroidea ve glandula parathyroidea'nın kızıl şahindeki konumlarının belirlenmesi amacıyla yapıldı. Çalışmanın materyalini fakültemiz kliniklerine getirilen ve kurtarılamayan sekiz adet ergin kızıl şahin (Buteo rufinus) oluşturdu. Glandula thyroidea'nın kızıl şahinde göğüs boşluğu girişinde furcula'nın iki kolu arasında yer aldığı görüldü. İncelenen bezler içerisinde en büyük olan glandula thyroidea'nın uzunluğu 4,5 $\pm 0,8 \mathrm{~mm}$, eni $2,87 \pm 0,53 \mathrm{~mm}$ ve kalınlığı ise $2,74 \pm 0,42 \mathrm{~mm}$ olarak saptandı. Büyüklük bakımından ikinci sırada olan glandula parathyroidea'nın sağda bir adet, solda ise genelde cranial ve caudal olmak üzere iki adet olduğu görüldü. Cranial'de yer alan glandula parathyroidea'nın uzunluğu $1,73 \pm 0,38 \mathrm{~mm}$, eni $1,13 \pm 0,18 \mathrm{~mm}$ ve kalınlığ $1,05 \pm 0,67 \mathrm{~mm}$ iken caudal glandula parathyroidea'nın uzunluğu 1,13 $\pm 0,23 \mathrm{~mm}$, eni $0,94 \pm 0,21 \mathrm{~mm}$, kalınlığı $0,59 \pm 0,16 \mathrm{~mm}$ olarak ölçüldü. Glandula ultimobranchialis'in sağlı sollu asimetrik olarak bulunduğu ve oldukça küçük şekillendiği görüldü. İncelenen materyallerde sol taraftaki glandula ultimobranchialis'in genellikle caudal glandula parathyroidea'nın caudal'inde ve arteria carotis communis'in başlangıcı düzeyinde yer aldığı belirlendi. Sağ tarafta yer alan glandula ultimobranchialis genellikle vena oesophagotracheobronchialis ile arteria

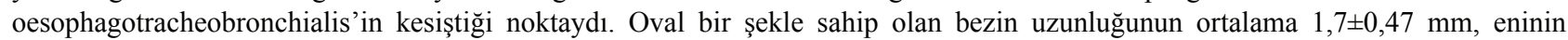
$0,94 \pm 0,35 \mathrm{~mm}$, kalınlığının ise $0,5 \pm 0,14 \mathrm{~mm}$ olduğu belirlendi. Sonuç olarak kızıl şahinde incelenen bezlerin lokalizasyonu diğer kanatlı türleri ile benzer iken glandula parathyroidea'nın sayısı ile diğer tüm bezlerin boyutunda farklılıklar görüldü.

Anahtar sözcükler: Anatomi, glandula parathyroidea, glandula thyroidea, glandula ultimobranchialis, kızıl şahin.

\section{Introduction}

Calcium is essential for the normal metabolic processes in birds. Calcium levels are regulated by different hormonal systems consisting of calsitonin secreted by ultimobranchial gland, parathormone secreted by parathyroid tissue, vitamin $\mathrm{D}$, and reproductive hormones such as estrogen. These systems interact to stabilize the plasma and to maintain the tissue calcium levels (7). In contrast to the mammals, birds have the $\mathrm{C}$ cells which are responsible for the production of calcitonin in the ultimobranchial gland instead of the thyroid $(13,15)$. Calcium related bird diseases can be due to many factors; and can lead to economic losses due to various clinical problems such as rickets, fall in egg

\footnotetext{
* This study was presented in VI. National Congress of Veterinary Anatomy, 16-19 September 2010, Afyon-Turkey
} 
production, thin-shelled egg production, egg retention, lattice strain $(2,11)$. Physiology of calcium metabolism of the birds has still being discussed in epidemic calcium imbalance disorder cases (7). Also, hyperplasia in the thyroid gland localized around the neck region that may be encountered can form in many avian species particularly in pigeons, budgerigars, canaries, and birds of prey, can be due to the foods containing iatrogenic agents as well as to goiter, septicaemic diseases, and toxication (5). As a result of mechanical pressure on the adjacent organs, vomiting, weight loss, respiratory distres, convulsions; even sudden death may be observed $(5,12)$.

In birds, the thyroid gland is not related with larynx unlike mammals, and is placed at the vascular angle formed by subclavian artery and common carotid artery just at the entrance of the thoracic inlet, as two seperate glands at the right and left $(6,8,14)$. The parathyroid gland are totally 2-4 numbers located between the ultimobranchial gland and the thyroid gland a long jugular vein (3). Ultimobranchial gland which includes calcitonin-secreting $\mathrm{C}$ cells, is a gland specific to amoeba, reptile and birds and it is generally located at the in the caudal side parathyroid gland $(3,8,14,15)$. The borders of the gland were irregular shape due to lack of the surrounding capsule (17).

There are previous studies on the morphologic structure and the topographic anatomy of the carotid body, thyroid gland, parathyroid gland and ultimobranchial gland of various avian species $(4,9,13,16,17)$. The purpose of this study is to identify the localization of the thyroid gland, parathyroid gland and ultimobranchial gland spesific to reptile and avian species and in long-legged buzzards and to contribute to the anatomy literature.

\section{Materials and Methods}

The material of the study consisted of eight adult unrecoverable long-legged buzzard (Buteo rufinus) referred to our faculty clinics for various reasons. The glands were identified under the Olympus SZ61 TRC trade mark stereomicroscope using dissection methods. The photographs were taken with the Olympus C-5060 digital camera after the macro anatomic findings were recorded. Measurements were taken with Mitutoyo digital calipers. Nomina Anatomica Avium was used for nomenclature (3).

\section{Results}

It was noted that in the long-legged buzzard the thyroid gland is oval in shape and it runs bilaterally between the two arms of the furcula at the entrance of the chest cavity (Figure 1a-2a). The left thyroid gland was in contact with common carotid artery. In six out of eight specimens the right thyroid gland was between common carotid artery and jugular vein; and in the remaining two specimens it was located on common carotid artery (Figure 2a). Among the glands examined length, width, and thickness of the largest thyroid gland were approximately $4.5 \pm 0.8 \mathrm{~mm}(4.7 \pm 0.9 \mathrm{~mm}$ on the right side - $4.3 \pm 0.7 \mathrm{~mm}$ on the left side), $2.87 \pm 0.53 \mathrm{~mm}(3 \pm 0.3 \mathrm{~mm}$ on the right side $-2.7 \pm 0.6 \mathrm{~mm}$ on the left side), and $2.74 \pm 0.42 \mathrm{~mm}(2.9 \pm 0.2 \mathrm{~mm}$ on the right side $-2.5 \pm 0.5$ $\mathrm{mm}$ on the left side), respectively. The second largest gland was parathyroid gland (Figure $1 b-2 b$ ). It was seen as a single gland on the right side in all the study specimens. This gland was either adjacent to the thyroid gland or at the caudal of the thyroid gland. In four specimens there were two numbers left parathyroid gland which were cranial and caudal. However, three specimens have a single gland; one specimen had three numbers (Figure 2b). The cranial parathyroid gland was seen close to thyroid gland or adjacent to it; the caudal parathyroid gland was seen at the caudal of the thyroid gland. The length, width, and thickness of the cranial parathyroid gland were approximately $1.73 \pm 0.38 \mathrm{~mm}$ (1.8 $\pm 0.4 \mathrm{~mm}$ on the right side $-1.6 \pm 0.3 \mathrm{~mm}$ on the left side), $1.13 \pm 0.18 \mathrm{~mm}(1.2 \pm 0.1 \mathrm{~mm}$ on the right side $0.9 \pm 0.1 \mathrm{~mm}$ on the left side), and $1.05 \pm 0.67 \mathrm{~mm}(0.9 \pm 0.3$ $\mathrm{mm}$ on the right side $-1.1 \pm 0.39 \mathrm{~mm}$ on the left side), respectively, where the length, width, and thickness of the caudal parathyroid gland were $1.13 \pm 0.23 \mathrm{~mm}$, $0.94 \pm 0.21 \mathrm{~mm}$, and $0.59 \pm 0.16 \mathrm{~mm}$ respectively. Ultimobranchial gland was observed as considerably small in size and as asymmetric on both sides (Figure 1c2c). The left ultimobranchial gland was at the caudal of the caudal parathyroid gland and was leveled at the begining of the common carotid artery in the majority of the study material. In two materials the mentioned gland was determined at the medial of the common carotid artery while in the others, it was at the lateral. Generally, right ultimobranchial gland was located in the junction of oesophagotrachebronchial vein and oesophagotrachebronchial artery. In one specimen the gland was observed at the caudal of the oesophagotrachebronchial vein and the ventromedial of the vagal nerve (Fig. 2c). No connection was established between the ultimobranchial gland and parathyroid gland neither at right nor et left. Average length, width, and tickness measurements of this oval shaped gland were approximately $1.7 \pm 0.47 \mathrm{~mm}(1.7 \pm 0.5$ $\mathrm{mm}$ on the right side- $1.7 \pm 0.4 \mathrm{~mm}$ on the left side), $0.94 \pm 0.35 \mathrm{~mm}(0.97 \pm 0.4 \mathrm{~mm}$ on the right side $-0.9 \pm 0.2$ $\mathrm{mm}$ on the left side), and $0.5 \pm 0.14 \mathrm{~mm}(0.6 \pm 0.17 \mathrm{~mm}$ on the right side $-0.5 \pm 0.1 \mathrm{~mm}$ on the left side) respectively.

\section{Discussion and Conclusion}

The thyroid gland, regulating the body weight, feather development, reproductive function and lipid metabolism in avian species was observed to be located at the entrance of the chest cavity as stated in literature $(6,13,14,16)$. In this study, the dimensions of the thyroid gland in long-legged buzzard were determined as smaller than the dimensions for chicken $(4,8)$, duck, goose, pigeon (8) and buzzard (16). Furthermore, the numbers of the long-legged buzzard at both sides were 


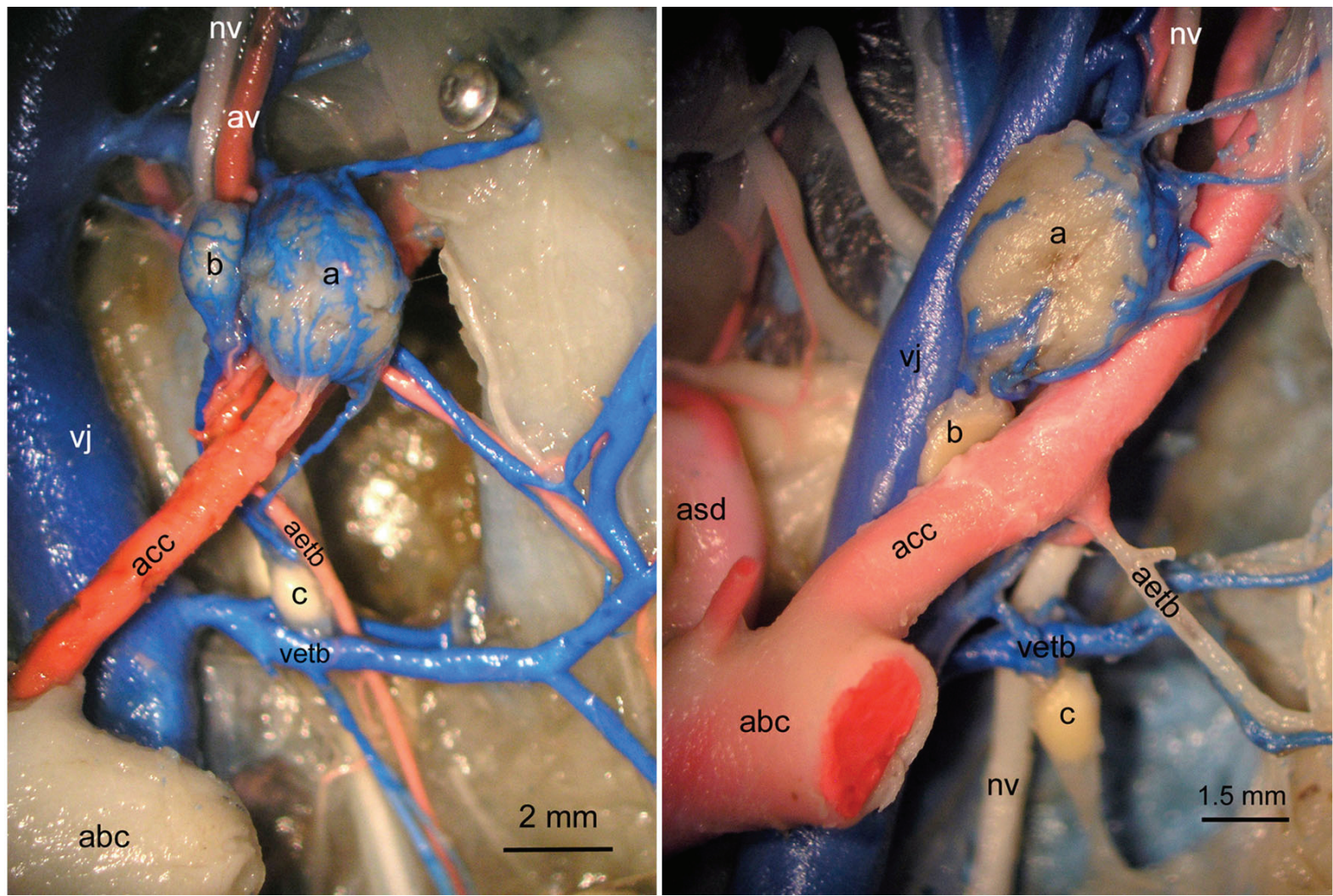

Figure 1: Right view of the thyroid gland, parathyroid gland and ultimobranchial gland in long-legged buzzard Şekil 1: Kızıl şahinde gl. thyroidea, gl. parathyroidea ve gl. ultimobranchialis’in sağ taraftan görüntüsü a: gl.thyroidea, b: gl.parathyroidea, c: gl.ultimobranchialis, abc: a.brachiocephalica, acc: a. carotis communis, vj: v. jugularis, nv: n.vagus, av: a.vertebralis, asd: a. subclavia dextra, aetb: a. esophagotracheobronchialis, vetb: v. esophagotracheobronchialis

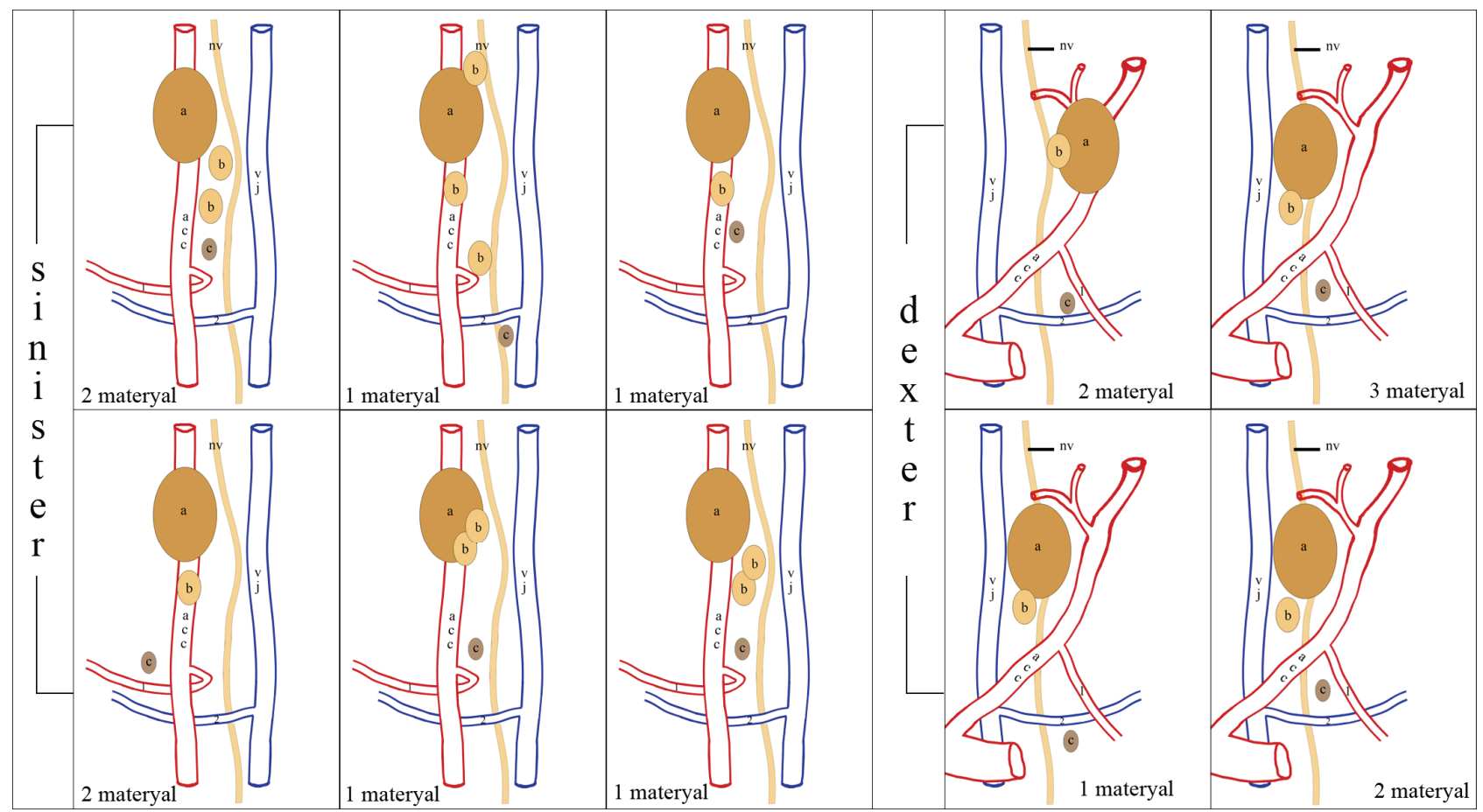

Figure 2:Left view of the thyroid gland, parathyroid gland and ultimobranchial gland in long-legged buzzard Şekil 2: Kızıl şahinde gl. thyroidea, gl. parathyroidea ve gl. ultimobranchialis'in şematik görünümü

a: gl. thyroidea, b: gl. parathyroidea, c: gl. ultimobranchialis, acc: a. carotis communis, vj: v. jugularis, nv: n. vagus, 1: a. esophagotracheobronchialis, 2 : v. esophagotracheobronchialis 
seen to be similar in size, in contrast to the significant dimension difference stated by Radek and Piasecki (16).

The parathyroid gland, which secrets parathormone to regulate calcium and phosphate metabolism, had seen to have similar shape and dimensions to the concerned by literature $(3,8,10,17)$. In literature $(1,10)$ it was reported that the parathyroid gland of the domestic birds consists of cranial and caudal gland touching each other and the right cranial parathyroid gland is in contact with thyroid gland where this connection do not exist at the left cranial parathyroid gland. In this study, parathyroid gland is identified as a single gland located on the rightside either adjacent to thyroid gland or at the caudal of the thyroid gland. Left parathyroid gland is identified as a single gland in three materials; two glands in four materials; and three glands in one material. The cranial parathyroid gland are found either near to the thyroid gland or adhered to it, where the caudal gland was observed at the caudal of the thyroid gland.

The most detailed information on the location and the size of the calcitonin-secreting ultimobranchial gland was given by Nickel (14) for chickens, ducks, geese and pigeons, Abdel-Magied and King (1) for poultry, Takagi and Yamada (17) for grass parakeet. Takagi and Yamada (17) indicated that this gland develops significantly smaller in grass parakeet compared to the other birds and they attributed this to the proportion regarding its small body weight. The measurements from the long-legged buzzards obtained in this study support this argument. It is reported that in the domestic poultry, it is easier to identify the left ultimobranchial gland than the right gland, since it is located just caudally to parathyroid gland and it is in touch with it (1). This study reveals differences in the location of the gland and establishes no connectivity to parathyroid gland on either side. In the long-legged buzzard, the left ultimobranchial gland was observed generally at the caudal of the caudal parathyroid gland and lateral to the common carotid artery, but in two materials this gland was in the medial of the common carotid artery. Right ultimobranchial gland was located at the intersection of the oesophagotrachebronchial vein and oesophagotrachebronchial artery in seven materials, but in one material it was located at the caudal of the oesophagotrochebronchial vein and at the ventromedial of the vagal nerve. Takagi and Yamada (17) reported that in parallel to the reptiles, in the grass parakeet the left gland was more developed than the right gland. In this study, a significant size difference was not observed between the glands on both sides.

In conclusion, a detailed identification of the location of ultimobranchial gland, the thyroid gland, and the parathyroid gland in the long-legged buzzards were determined. The dimensions of these glands were compared to the dimensions from the other bird species; the similarities and the differences were identified. Furthermore the similarities and the differences from other bird species in regard to dimensions were presented. Our opinion is that the findings of this study will contribute to the anatomy literature as a valuable resource for future researchers focused on this subject.

\section{References}

1. Abdel-Magied EM, King AS (1978): The topographical anatomy and blood supply of the carotid body region of the domestic fowl. J Anat, 128(3), 535-546.

2. Austic RE, Scott ML (1997): Nutritional Diseases. 47-73. In: Calnek BW, Barnes HJ, Beard CW, McDougald LR, Saif YM (Ed), Diseases of poultry. Iowa State University Press, Mosby-Wolfe, London.

3. Baumel JJ, King AS, Breazile JE, Evans HE, Vanden Berge JC (1993): Nomina Anatomica Avium. MA: Nuttall Ornithological Club, Cambridge.

4. Breit S, König HE, Stöger E (1998): The morphology of the thyroid gland in poultry with special regard to seasonal variations. Anat Histol Embryol, 27(4), 271-276.

5. Butcher GD, Beck CC (1993): Avian Goiter (Thyroid Hyperplasia or Dysplasia). Erişim: http://edis.ifas.ufl.edu. Erişim Tarihi: 06.04.2011.

6. Getty R (1975): Sisson and Grossman's the Anatomy of the Domestic Animals. WB Saunders Company, New York.

7. Johnston MS, Ivey ES (2002): Paratyroid and ultimobranchial glands: Calcium metabolism in birds. Semin Avian Exotic Pet Med, 11, 84-93.

8. Kahvecioğlu O, Çalışlar T (2002): Ürogenital ve endokrin sistemi, Evcil Kuşların Anatomisi.123-127. Ed. Dursun N, Medisan Publisher, Ankara.

9. Kameda Y (2002): Carotid Body and Glomus Cells Distributted in the Wall of the common Carotid Artery in the Bird. Microsc Res Tech, 59, 196-206.

10. King AS, McLelland J (1984): Birds: Their Structure and Function. London: Bailliere Tindall.

11. Kurtdede A (2001): Kafes kuşlarının muayenesi ve hastalıklarl. Azim matbaacilık, Ankara.

12. McLelland J (1990): A Color Atlas of Avian Anatomy. Wolfe Publishing Ltd, London.

13. Merryman JI, Buckles EL (1998): The avian thyroid gland. Part One: A review of the anatomy and physiology. J Avian Med Surg, 12(4), 234-237.

14. Nickel R, Schummer A, Seiferle E (1977): Anatomy of the Domestic Birds. Berlin-Hamburg: Verlag Paul Parey.

15. O'Malley B (2005): Clinical anatomy and physiolojgy of exotic species "Structure and function of mammals, birds, reptiles, and amphibians'. 144-145. Elsevier Saunders, Toronto.

16. Radek T, Piasecki T (2007): Topography and arterial supply of the thyroid and paratyroid glands in selected species of falconiformes. Anat Histol Embryol, 36, 241-249.

17. Takagı I, Yamada K (1984): A Morphological Study of the Ultimobranchial Body in the Grass Parakeet. Arch Histol Jap, 47(4), 377-385.

\section{Geliş tarihi: 28.04.2011 / Kabul tarihi: 22.09.2011}
Address for correspondence:
Yrd. Doç. Dr. Burcu ONUK
Department of Anatomy, Faculty of Veterinary Medicine,
University of Ondokuz Mayis,
55139 Kurupelit, Samsun-TURKEY
e-mail: burcuonuk@,omu.edu.tr 